\title{
Thought on Practice Teaching of Vocation Education Based on Modern Apprenticeship
}

\author{
Zhiguo Meng ${ }^{1}$ and Haiyan Wang ${ }^{1}$ \\ ${ }^{1}$ College of Information Technology, Guangdong Industry Technical College, Guangzhou, China \\ No.152 of Guangzhou Xingang West Road Postal Code 510300 \\ mzg168@sina.com
}

Keywords: Practice teaching; Vocation education; Modern apprenticeship; Combination culture system; Semiconductor lighting profession

\begin{abstract}
Modern apprentice system is a hot spot in the field of vocational education. The research aims to strengthen the cooperation between the school and enterprises, to solve the problems such as model of joint training practice, management, teaching, training and other issues. The modern apprenticeship which we used for research introduces the government and industry association to guide a personnel training mode, to promote deeply cooperation between school and enterprises. The teacher and enterprise supervisor undertake education and training to the students who complete professional practice and finish the production as the similar employees in the enterprise. Thus, they can further develop the core skills. Through the establishment of the work in the pilot system, it can reform independent evaluation model of the school and enterprises to perfect various curriculum evaluation criteria. In practices, it highlights the educational philosophy of modern apprenticeships. The practice has proved that students possess solid professional knowledge through the joint training. A third party investigation said that our part of student compound applied talents and high quality technology.
\end{abstract}

\section{Introduction}

Modern apprentice system is a hot spot in the field of vocational education. The related research on higher vocational colleges informs a theoretical foundation for the modern apprenticeship pilot. The specific implementation of modern apprenticeship in higher vocational colleges provides the practical basis of both at home and abroad pilot apprenticeship (Lin Lichun etc., 2015).

In practice teaching, the effective implementation of modern apprenticeship is made with fusion, even is the basic trend in the development of vocational education specific professional and leading mode. Apprenticeships can strengthen the cooperation both of the school and enterprises. The combination of teachers, which reflect a new work-integrated learning personnel training mode, help to solve the new problems such as weak professional practice conditions, and to provide for the industrial upgrading of regional economy and professional construction of vocational education.

\section{Implied Meaning}

Apprenticeship as a new form of modern education declines with both economic and social development. Its survival and development of vocational and technical education in the form of real demand is also the result of the vocational and technical education constantly soul-searching. Modern apprenticeship is the inheritance and development of traditional apprenticeship that emphasize in the real work in the scene experience learning activities (Xiao-yan Yang. 2012).

It is not only a way of technology transfer, and modern vocational education significance. Apprenticeship in recent years, is each country attaches great importance to, such as the UK has formulated the review( Xiao-yan Yang. 2012) of the apprenticeship program, Germany and other 
countries in the "dual system" vocational education based on the modern apprenticeship system, Australia new apprentice system is put forward.

China's vocational education actively explore "modern apprenticeship" personnel training mode, in the summary under the planned economic system of enterprise operation mechanism and characteristics of mechanic education, on the basis of advanced the theory of "modern apprenticeship" pattern, this pattern of current university-enterprise cooperation has important guiding significance to ( $\mathrm{Xu}$ Jinlin etc., 2013).From the traditional apprenticeship to modern apprenticeship, vocational education "higher character" which gives its new connotation.

Modern apprenticeship run around all-round development and sustainable development, further deepen the reform of work-integrated learning personnel training mode. From university-enterprise cooperation platform construction, the reconstruction of the learning carrier, teaching organization and the management pattern of change, teaching team agglomeration and the culture value orientation, teaching evaluation and so on. The implementation of the system elaborated the modern apprenticeship elements ( Zhen-hong etc.,2012).

Reflecting the government guidance, a modern personnel training mode of cooperation between the school and the jointly enterprise, which run at part time in enterprise production, at part of the time in school again, which master by vocational colleges and enterprises jointly to undertake the student to education and training.

Its characteristic is to realize the class enrollment namely hiring, mount guard, graduate employment. Learning as employment, the professional work experience help to the professional person, smooth transition of student, which is favorable to promote the enterprises to participate in the whole process of vocational education personnel training, to promotes the fusion of universityenterprise cooperation such as professional settings, industrial demand, teaching process, the production process integration, graduation certificate and professional qualification certificate, the full implementation of quality education. Therefore, the establishment of modern apprenticeship is a requirement of vocational education which initiative service economic society, deepen integration education, realize the sustainable development of vocational colleges and enterprises.

\section{Experiments in Professional Practice}

Semiconductor lighting industry in urgent need of technology research and development personnel, management personnel and marketing pr class talented person, the higher vocational talents training is focused on the industrial manufacturing jobs, in the higher vocational school to carry out the cooperation between colleges and enterprises, fosters the talent ( National semiconductor lighting project research and development and industry alliance, 2013).Proactive companies will research and development center functions built into the campus, some extend the practical conditions in colleges and universities to the enterprise workshop, within the enterprise, some college in university-enterprise cooperation on the basis of field work and ordering cultivation, to explore the modern apprenticeship "dual education, post up" the basic characteristics of talent cultivation model( Peng-fei zhao etc.,2013).

We try out the "modern apprenticeship" he trained personnel in semiconductor lighting industry, but also because the main training technicians and management personnel at the grass-roots level by enterprises. The joint training of medical students should have solid knowledge of semiconductor lighting application technology to become the compound applied talents with high quality through the cooperation between colleges.

A trial basis "modern apprenticeship" university-enterprise joint training mode on Guangzhou XX photoelectric co., LTD. , professional use three years of schooling students, which are mainly in the school culture in the first two years, in the enterprise implement multiple positions and on-the-job training the third year students. Students in school learning this professional basic theoretical knowledge; Last time more than half of the main study in business practice, guiding students jointly 
by schools and companies, enterprise credit appraisal practice during the complete school, concrete practice content in combination with the practical situation of the enterprise by the unit will be negotiated with schools and students.

According to enterprise, the photoelectric position requirements, and the characteristics of professional personnel training, the two sides jointly developed the professional talent training scheme of modern apprenticeships. According to the training plan, meet the training requirements, the implementation of the double tutorial system. According to the modern apprenticeship "four pairs of" basic characteristics, namely: the double main body education, two teachers teaching, students' dual identity and sign two contracts, the joint between colleges establish management and operation mechanism of modern apprenticeship pilot.

Students in school during the study, adopted between double mentor, team teaching way of implementing the school culture. As an apprentice in enterprise during the period of study, students identify professional teachers as a mentor to photoelectric company guidance theory of learning; which send technicians to be teachers, is responsible for the intern position skills. As one of the important position in teaching factory, which pay attention to ability training and skill training, to promote knowledge, skills, training and working practice, promote the unity of the teaching, learning, doing, achieve all-round development of students. School has established the full-time teachers of related appraisal system of enterprise practice, technical services, the company will establish master relevant responsible for teaching appraisal system. Both parties mutually by personnel interoperability with two-way, promote smoothly the pilot work and the professional construction, transverse joint research and development at the same time.

In order to improve the students' skill level as the goal, according to the "student - apprentice to prospective employees, employees" four one of the general idea of personnel training, implements the higher education system, 1-2 year students in the school to complete foundation and quality courses, professional foundation courses learning tasks, to master the basic skills required for a professional, student experience, imitate, try, understand the enterprise culture; 3 year in the form of " $0.5+0.5$ " to complete the professional core course, develop curriculum and the comprehensive ability of learning task, half a year in the form of "the apprentice" in "rotational training of enterprise, the last six months in the form of" employee "in" field work ".At the same time, implement enterprise team management mode, a teacher took about 5 disciple, form study groups, to ensure the students to master the skills needed for the internship. Professional skill requirements and training content are determined jointly by schools and enterprises. Students graduated from the professional qualification certificate at the same time.

In order to ensure the smooth operation of the pilot work, school and enterprise professional pilot system cooperation agreement, students signed with enterprises in the third year on-the-job training agreement, become a formal apprenticeship, enjoy treatment of employees. After a training mode "apprenticeship" he trained graduates, through learning practice, in the enterprise hope to students in the semiconductor lighting upstream, midstream, or downstream photoelectric products manufacturing, design, research and development, performance test and operation management, and other practical skills has improved, semiconductor lighting packaging research and development and production management ability; Semiconductor lighting design and construction ability; Semiconductor lighting application design ability.

Student work style to rigorous practical, autonomous learning ability, communication skills, team cooperation ability, management ability, interpersonal relationship handling ability and scientific research ability is more conform to the requirements of the company position. Through the internship at the grass-roots level, more solid talent base, research and development work closer to the actual situation, the following table provides a packaging technician positions during the practice of training plan. 
Table 1 Post practice plan to packaging technician

\begin{tabular}{|l|l|l|}
\hline \multicolumn{1}{|c|}{ course } & \multicolumn{1}{|c|}{ Training methods } & \multicolumn{1}{c|}{ time } \\
\hline $\begin{array}{l}\text { Semiconductor lighting packaging production } \\
\text { technology training }\end{array}$ & $\begin{array}{l}\text { Practice within } \\
\text { workshop }\end{array}$ & More than 6 months \\
\hline $\begin{array}{l}\text { Reliability test of semiconductor lighting } \\
\text { knowledge training and field }\end{array}$ & $\begin{array}{l}\text { School (or the } \\
\text { enterprise ) practice }\end{array}$ & $1 \sim 2$ weeks \\
\hline $\begin{array}{l}\text { Semiconductor lighting automation equipment to } \\
\text { learning and speaking }\end{array}$ & $\begin{array}{l}\text { School (or the } \\
\text { enterprise ) practice }\end{array}$ & $1 \sim 2$ weeks \\
\hline $\begin{array}{l}\text { Semiconductor lighting engineering test and can } \\
\text { issue the test report }\end{array}$ & $\begin{array}{l}\text { School (or the } \\
\text { enterprise ) practice }\end{array}$ & $1 \sim 2$ weeks \\
\hline $\begin{array}{l}\text { Semiconductor lighting encapsulation equipment } \\
\text { calibration, maintenance and debugging, etc }\end{array}$ & $\begin{array}{l}\text { School (or the } \\
\text { enterprise ) practice }\end{array}$ & $1 \sim 2$ weeks \\
\hline
\end{tabular}

During the teaching practice, the students' graduation design and thesis, according to their respective positions, engineers in the enterprise in the enterprise under the guidance of the teacher and school completed, enterprises provide the necessary environment and conditions for this purpose.

\section{Thinking of Professional Training}

Enterprise demand for skilled workers is diverse, according to the result of survey of enterprises and schools, we summarized the enterprise need most of the big four positions, refined skills, and corresponding core skills specialized core curriculum arrangement in the fifth semester in enterprises. The fifth semester students will form "the apprentice" and "rotational training of enterprise, to carry on the specialized core course of study at the same time, the teacher and school teachers by the enterprise with the primary cultivation of core skills for students. On sixth semester, students will become the form "employees" to "field work" in the enterprise, to the cultivation of core skills further.

Outstanding ability as the standard, the reform in the past the school independent assessment evaluation mode, both schools and enterprises, improve various curriculum appraisal standards, make assessment standards will highlight the educational requirements of modern apprenticeships. For strong theoretical foundation and quality courses, professional foundation courses, development courses, with "knowledge + skill" appraisal method, which lay particular stress on the proportion of the knowledge assessment. For practical strong professional foundation courses, professional core courses, comprehensive ability classes, etc., by "+ professional knowledge + skill" examination methods, focus on skills, professional quality assessment. In order to better implement "knowledge + skill" or " professional +knowledge + skill" assessment methods, such as, "process evaluation" and "should be" assessment of results ", combining modern apprenticeship to more accurate evaluation on the students, improve students' ability in employment base, post core ability, professional migration ability, to achieve "everyone has skills, each has a special" goal.

Under modern apprenticeship students has a dual identity school students and enterprise employees, should observe the rules and regulations of the school, enterprises at the same time. During the period of apprenticeship, Students have all-the-way tracking, and actively cooperate with teachers pay close attention to students' study and life. At the same time, it set up various types of scholarships and financial aid forms, motivate students to learn professional knowledge and skills, reserve talents for the enterprise.

Need to gradually establish a working system, set up special field management institutions, making them management process, and improve the administration system of the field, establish a strict training before them and access system. To strengthen the practice labor safety education of students, students comprehensively strengthen field management work, set up schools, parents photoelectric and regular field information reporting system. Use of existing teaching management system, semiconductor lighting professional field platform norms such as Shared resources class 
students archives management, strengthen supervision and inspection, to ensure health, safety and orderly conduct field work.

\section{Result and Discussion}

A double mentor team between colleges and company has been adopted to implement training school. Teachers who pay teaching way supplement other sides through double tutors in the enterprises. Students that have signed the on-the-job training agreement can implement more on-thejob training, then become a formal apprenticeship, enjoy treatment of enterprise prospective employee. Modern apprenticeship further promoted the cooperation between colleges and training technical personnel of industry at the same time. Teachers will have deeply understanding to "industry-institute cooperation", also these engineers will expand technical cooperation, staff training and other fields.

\section{Acknowledgment}

This paper was partly supported by professional teaching resource database construction project (No.2015-3) on vocational education, the Ministry of Education, China

\section{References}

[1] Lin Lichun. Modern apprenticeship in the research and practice of higher vocational education. Journal of light industry technology. 2015.02,pp:137-139

[2] Xiao-yan Yang. Exploration and practice of modern apprenticeship [J]. Journal of vocational education BBS. 2012.09,pp:23-26

[3] Xu Jinlin Long Fengxiu. "modern apprenticeship" theoretical model and the reality enlightenment. Journal of contemporary vocational education. 2013.09,pp:211-214

[4] Zhen-hong wang cheng. Modern apprenticeship: highly skilled personnel training new paradigm. China's higher education research. 2012.08,pp:67-70

[5] National semiconductor lighting project research and development and industry alliance. The semiconductor lighting industry skill talent development guide. China light industry press. 2013.11

[6] Peng-fei zhao. Exploration and practice of modern apprentice system. Journal of vocational and technical education in China. 2013.10,pp:45-48 